\title{
EUROPEAN UNION CITIZENSHIP: WRITING THE FUTURE
}

\section{Dora Kostakopoulou}

\author{
(Law, University of Manchester \\ Email address: dora.k@man.ac.uk)
}

\section{INTRODUCTION}

In the 1990s scholars sought to address the legitimacy, content and impact of the institution of European Union citizenship, which was established by the Treaty on European Union in 1992, encompassing normative, empirical and institutional points of view. ${ }^{1}$ Most scholars saw European citizenship as a purely decorative and symbolic institution, which added little new to the 'pre-Maastricht' regime of free movement rights. ${ }^{2}$ In addition, many felt the need to defend the primacy of national citizenship by highlighting the derivative nature and weak content of

\footnotetext{
${ }^{1}$ Closa, 'The Concept of Citizenship in the Treaty of European Union' (1992) 29 Common Market Law Review 1137; 'Supranational Citizenship and Democracy: Normative and Empirical Dimensions', in La Torre (ed.), European Citizenship: An Institutionalist Challenge (Kluwer, 1998); Meehan, European Citizenship (Sage, 1993); Kostakopoulou, 'Towards a Theory of Constructive Citizenship in Europe', Citizenship, Identity and Immigration in the European Union: Between Past and Future (1996) 4(4) Journal of Political Philosophy 337; (Manchester University Press, 2001); Preuss, 'Two Challenges to European Citizenship', (1996) XLIV Political Studies 534; Shaw, 'The Many Pasts and Futures of Citizenship in the EU' (1997) 22 European Law Review 554; A. Wiener, 'Assessing the Constructive Potential of Union-Citizenship - A Socio-Historical Perspective' (1997) 1(17) European Integration Online Papers (http://eiop.or.at/eiop/); Wiener and Sala, 'Constitution-making and Citizenship Practice Bridging the Democracy Gap in the EU?’, (1997) 35(4) Journal of Common Market Studies 595; Bellamy and Castiglione, 'The communitarian ghost in the cosmopolitan machine: constitutionalism, democracy and the reconfiguration of politics in the New Europe', in Bellamy and Castiglione (eds), Constitutionalism, Democracy and Sovereignty: American and European Perspectives (Avebury, 1996); Bellamy and Warleigh (eds), Citizenship and governance in the European Union (Continuum, 2001).

${ }^{2}$ In addition to constitutionalising the pre-existing rights of free movement and residence (former Article 8a EC), Union citizenship included the right to vote and stand as a candidate for local and European Parliament elections in the Member State of residence (Article 8b EC), the right to protection by diplomatic and consular authorities of any members state in a third country where a citizen's own member state is not represented (Article 8c EC) and the right of access to non-judicial means of redress through the Ombudsperson and though petitions to the European Parliament (Article 8d EC).
} 
European citizenship. ${ }^{3}$ Quite often assumptions derived from the national order and national citizenship framed the discussion and theorising about European citizenship in such a way that the issue of its transformative potential remained at the margins of the debate.

Despite such minimalist assessments, however, European Union citizenship has matured as an institution, owing to a number of important interventions by the European Court of Justice over the last ten years and legislative initiatives, such as the so called Citizenship Directive (Dir 2004/38) which has entered into force. ${ }^{4}$ The transformative potential of Union citizenship has clearly shifted from the margins to the centre, thereby prompting an examination of the process by which European citizenship has acquired specificity, substance and increasing complexity and its relationship with national and cosmopolitan forms of citizenship. In this article, I contend that by focusing explicitly on European Union citizenship in its context, which is within an existing framework of nested and interacting citizenships fashioned at various levels of governance, we can appreciate fully the distinctiveness, radicalism and impact of European citizenship, which are far more extensive than portrayed by the literature.

In what follows, I critically examine minimalist and cosmopolitan conceptions of European citizenship (sections 1 and 2) and argue that once we dispense with the preoccupation of assigning primacy to a specific level of citizenship and establishing some kind of hierarchy among them, we can begin to address the questions and issues that really mater. Among these are the future governance of citizenship in a post-Westphalian settlement and the design of a more inclusive, multilayered and multicultural conception of citizenship (section 3). For European citizenship constitutes a unique experiment for stretching social and political bonds beyond

\footnotetext{
3 Lyons, 'Citizenship in the Constitution of the EU: Rhetoric or Reality?', in Bellamy (ed), Constitutionalism, Democracy and Sovereignty: American and European Perspectives (Avebury, 1996); Everson, 'The Legacy of the Market Citizen', in Shaw and More (ed), The New Dynamics of European Union (Clarendon Press, 1995); Vink, Limits of European Citizenship (Universal Press, 2003); Lehning, 'European Citizenship: a mirage?, in Lehning And Weale (eds), Citizenship, Democracy and Justice in the New Europe (Routledge, 1997); Baubock, 'Citizenship and National Identities in the European Union', (1997) 4 Harvard Jean Monnet Working Paper 97.

${ }^{4}$ European Parliament and Council Directive 2004/38/EC, OJ 2004 L 158/77. Directives 68/360, 73/148, 72/194, 75/34, 75/35, 90/364, 90/365, 93/96 and 64/221 were repealed with effect from 30 April 2006.
} 
national boundaries and for creating a political community in which diverse peoples become associates in a collective experience and institutional designers. European citizenship thus entails a number of fruitful ideas for a more ambitious transition to a post-national tableau and can be the prototype for institutional experimentation on citizenship on a global scale.

\section{A PIE IN THE SKY?}

The establishment of European Union citizenship by the Treaty on European Union (1992) represented a unique historical moment. For the first time in the history of the Westphalian political order a concrete citizenship design beyond the nation-state had emerged, thereby undermining the exclusivity of national citizenship. But this historically unprecedented moment did not capture the political imagination to a large extent. Most scholars and policy-makers saw European citizenship as a purely decorative and symbolic institution. ${ }^{5}$ There existed several reasons for this. First, the content of European citizenship was rather limited. European citizenship was premised on the pre-existing Community law rights of free movement and residence and, with the exception of electoral rights at local and European Parliament and the right to diplomatic and consular protection when travelling abroad, did not add much new to existing Community law. In addition, the citizenship provisions did not include any reference to the duties owed by European citizens. For sure, if one juxtaposes such a modest content to that of national citizenship, which often embraces the Marshallian triptych of civil, political and social

\footnotetext{
${ }^{5}$ Everson, 'The Legacy of the Market Citizen', in Shaw and More (eds), New Legal Dynamics of European Union (Oxford University Press, 1995); J. d'Oliveira, 'Union Citizenship: Pie in the Sky?', in Rosas and Antola (eds), A Citizens’ Europe: In search of a New Order (Sage, 1995); P. Lehning, ‘European Citizenship: a mirage?', in Lehning and Weale (eds), Citizenship, Democracy and Justice in the New Europe (Routledge, 1997) 175; T. Downes, 'Market Citizenship: Functionalism and Fig-leaves', in Bellamy and Warleigh (eds), Citizenship and Governance in the European Union (Continuum, 2001) 93.
} 
rights and responsibilities, one may legitimately conclude that European citizenship was nothing more than a pale shadow of its national counterpart. ${ }^{6}$

Secondly, whereas national citizenship premises citizens' claims and entitlements on the basis of a historically developed, rich notion of membership in a national community, European citizenship appeared to comprise a core of economic entitlements primarily designed to facilitate market integration. ${ }^{7}$ Scholars pinpointed, for instance, that Union citizenship was the mirror image of pre-Maastricht market citizenship; that is, it reflected a loose and fragmented form of mercantile citizenship designed to facilitate the European integration. ${ }^{8}$ Such a minimalist conception Union citizenship accorded priority to the economic interests of private individuals at the expense of other important dimensions of citizenship, such as active involvement and political participation in the polity, the cultivation of a sense of political belonging, special duties owed to fellow citizens and redistributive concerns. In addition, it appeared to be relevant to a favoured group of EU nationals, that is, to minority of EU citizens who possess the necessary material resources required for intra-EU mobility. ${ }^{9}$

Thirdly, European citizenship was seen to have a weak affective dimension. Unlike national citizenships, which reflect strong national identities and the horizontal ties of belonging to a nation, conceived of as either a homogeneous ethnocultural community (ethnic nation) or a community of shared values (civic nation), European citizenship was going to help construct a European demos and to elicit subjective identification with the European Union. As the Commission stated in its third report on Union citizenship, 'the latter institution is both a source of legitimation of the process of European integration, by reinforcing the participation of citizens, and a fundamental factor in the creation among citizens of a sense of belonging to the European

\footnotetext{
${ }^{6}$ See d'Oliveira, loc cit, n 6, 1995; 'European Citizenship: its meaning its potential', in Dehousse (ed), Europe after Maastricht: An Ever Closer Union? (Beck, 1994).

${ }^{7}$ Everson, loc cit, n 6, 1995.

${ }^{8}$ Vink, loc cit, n 3, 2003.

${ }^{9}$ In January 2003, the number of mobile EU nationals was estimated to be 6.95 million; Commission figure available at the europa website, cited by Chalmers et al, EU Law (Cambridge University Press, 2006, p 572.
} 
Union and of having a genuine European identity' ${ }^{10}$ The main difficulty, here, is that collective identities remain firmly embedded within the national-statist environments. Indeed, a simple exercise of projecting processes of national identity formation onto the EU can easily reveal that the latter lacks those 'pre-political elements', that is, the spiritual, social and cultural ties that bind the people together. ${ }^{11}$ As the literature in the mid-1990s stated, the EU does not have a fully fledged European demos, at least not yet. ${ }^{12}$ True, critics would raise doubts concerning the appropriateness of such an exercise, given the fact that the European Union is neither an extension nor the mirror image of national-statist jurisdictions, as well as its accuracy since the exercise underestimates the historical and political processes of collective identity formation.

Finally, although the establishment of a supranational citizenship in 1992 showed that citizenship can no longer be confined within the national-statist setting, the nationality model of citizenship prefigured European citizenship. Union citizenship has been conditioned on the tenure or acquisition of national citizenship (Article 17(1) EC). As a consequence, the Member States remain the gatekeepers who control entry to the privileged European demos. Making European citizenship derivative of national citizenship does not only give prominence to the nationality principle, but, perhaps more worryingly, subjects membership to the European public to the definitions, terms and conditions of membership prevailing in national publics. As the Declaration on Nationality of a Member State, annexed to the Final Act of the Treaty on European Union, expressly stated, 'the question whether an individual possesses the nationality of a Member State shall be settled solely by reference to the national law of the Member State concerned'. Similar declarations were adopted by the European Council at Edinburgh and Birmingham. The Birmingham declaration confirmed that, in the eyes of national executives,

\footnotetext{
${ }^{10} \mathrm{COM}$ (2001) 506 final.

${ }^{11}$ Grimm, 'Does Europe need a Constitution?’, (1995) 1(3) European Law Journal 282; Smith, 'National Identity and the Idea of European Unity', (1992) 68(1) International Affairs 55.

${ }^{12}$ Weiler, 'Does Europe need a constitution? Reflections on demos, telos and the German Maastricht decision', (1995) 1(3) European Law Journal 219; 'To be a European citizen - Eros and civilisation', (1997) 4(4) Journal of European Public Policy 495. But compare Rubio-Marin’s contribution to La Torre’s edited collection, European Citizenship - An Institutional Challenge (Kluwer, 1998).
} 
Union citizenship constitutes an additional tier of rights and protection which is not intended to replace national citizenship - a position that found concrete expression in the amended Article 17(1) at Amsterdam. ${ }^{13}$ The European Court of Justice has by and large upheld the international law maxim that determination of nationality falls within the exclusive jurisdiction of the Member States, despite the anomalies that this creates in the filed of application of EC law and its exclusionary implications with respect to the rights of long term resident third country nationals. In Micheletti, the ECJ confirmed that determination of nationality falls within the exclusive competence of the Member States, but it went on to add that this competence must be exercised with due regard to the requirements of Community law, ${ }^{14}$ and in Kaur it stated that 'it is for each Member State, having due regard to Community law, to lay down the conditions for the acquisition and loss of nationality. ${ }^{15}$ This, essentially, means that persons who are legally recognised to be nationals of a Member state should be able to exercise their rights to free movement without impediments imposed by additional regulations adopted by other Member States.

In Chen, the European Court of Justice criticised the restrictive impact of such additional conditions for the recognition of nationality of a Member State. It ruled that the United Kingdom had an obligation to recognise a minor's (Catherine Zhu) Union citizenship status even though her MS nationality had been acquired in order to secure a right of residence for her mother Chen, a third country national, in the United Kingdom. Since Catherine Zhu had legally acquired Irish nationality under the ius soli principle enshrined in the Irish Nationality and Citizenship Act 1956 and had both sickness insurance and sufficient resources, provided by her mother, the limitations and conditions referred to in Article 18 EC and laid down by Directive 90/364 had been met

\footnotetext{
${ }^{13}$ Bull. EC 10-1992 I 8.9. The Amsterdam Treaty added the statement that 'Union citizenship shall complement national citizenship' to Article 8(1) EC (Article 17(1) on renumbering).

${ }^{14}$ Case C-369/90 Micheletti and Others v Delegacion del Gobierno en Catanbria [1992] ECR I- 4329.

${ }^{15}$ Case C-192/99 R v Secretary of State for the Home Department, ex parte Kaur [2001] ECR I-1237, para 19.
} 
thereby conferring on her an entitlement to reside for an indefinite period in the UK. ${ }^{16}$ Further, in Spain $v U K$, the Court held that the determination of the beneficiaries of the Union citizenship rights to vote and to stand as a candidate for EP elections falls within the competence of the MS, which must be exercised in compliance with Community law, ${ }^{17}$ and that Articles 189, 190, 17 and 19 EC do not preclude the MS from extending these rights to certain persons who have close links to them, other than their own nationals or citizens of the Union who are resident in their territory. ${ }^{18}$

Owing to the foregoing reasons, scholars and commentators concluded that the institution of European citizenship was simply not enough to induce real institutional change. Its value was more symbolic and instrumental. After all, the enumeration of a set of citizen entitlements in the Treaty could not but enhance the European Union's social legitimacy. But this perspective underestimated the 'constructive potential' of Union citizenship and the extent to which it would penetrate national citizenship, thereby effecting incremental, but transformative, institutional change. ${ }^{19}$ A rival, constructivist perspective did not hesitate to view European citizenship as a marker of a wider socio-political transformation. The latter was associated with a renewed focus on longstanding concerns about the maintenance of nationality as a proxy for defining political community; the changes effected by globalisation and the proper functioning of domestic institutions in an interdependent and highly complex world; the emergence of mutli-level governance and transnationalism; and the effects of the replacement of the ideal of national

${ }^{16}$ Case C-200/02 Kunqian Catherine Zhu and Man Lavette Chen v Secretary of State for the Home Department, Judgement of the Court of 19 October 2004.

${ }^{17}$ See also Case C-300/04 Eman and Sevinger, Judgement of the Court of 18 September 2006.

${ }^{18}$ Case C-145/04 Spain v United Kingdom, Judgement of the Court of 18 September 2006.

${ }^{19}$ Meehan, European Citizenship (Sage: 1993); Kostakopoulou, 'European Citizenship and Immigration after Amsterdam: silences, openings, paradoxes', (1998) 24 Journal of Ethnic and Migration Studies 639; Kostakopoulou, "Nested "Old" and "New" Citizenships in the European Union: Bringing Forth the Complexity', (2000) 5(3) Columbia Journal of European Law 389; T. Kostakopoulou, Citizenship, Identity and Immigration in the European Union (Manchester University Press 2001); Wiener, Building Institutions: The Developing Practice of European Citizenship (Westview, 1998); Shaw, 'The Interpretation of European Union Citizenship', (1998) 61(3) Modern Law Review; U. Vogel, 'Emancipatory politics between universalism and difference: Gender perspectives on European Citizenship', in Lehning and Weale (eds), Citizenship, Democracy and Justice in the New Europe, (Routledge, 1998) 142. 
homogeneity with multiplicity and diversity, on the one hand, and of conformity with reflexive identities and critical forms of belonging, on the other, for democracy and citizenship in the $21^{\text {st }}$ century. On this reading, the constraints of Union citizenship’s existing political and legal structures were seen as neither fundamental flaws nor limits; instead, they were viewed as opportunities for institutional modification and for building a political community on purely political grounds. In other words, the main deficiency of the European Union, namely, the lack of a primordial substratum and/or cultural commonalities was, in the view of constructivists, its principal advantage and the main reason for its normative appeal. Form this point view, European citizenship constituted a unique experiment for stretching social and political bonds beyond national boundaries and for creating a political community in which diverse peoples become associates in a collective experience and institutional designers. Europe could thus become the setting for the more ambitious transition to a post-national tableau and the prototype for cosmopolitan experimentation on a global scale.

\section{COSMOPOLITAN CITIZENSHIP AND THE POSTNATIONAL CONDITION}

The European Union is a unique, experimental political arrangement. Born out of historical conflict and the pressing need to overcome the destructive tendencies of nationalism, the European Union represents a post-Westphalian order which can function effectively without the support of a settled institutional structure and a concrete, shared finalite. Indeed, a key difference between the EU and national polities is that the former is, without a doubt, a community of communities. Endowed with equal status and an equal opportunity to shape its institutional configuration and further evolution, the Member States are entangled in an ongoing project of political experimentation which entails as much interdependence and a shared quest for improved institutional arrangements as contestations, collisions and strife. Owing to EU membership, the Member States have been forced to interrogate the doctrine of sovereignty, to learn to trust each 
other and to accept 'Europe's' impact upon their organising principles, institutions and policies. Indeed, what sustains the European Union as a community of communities is not the Member States' identification with it. Rather, it is their willingness to participate in the ongoing adventure, to engage with each other in various types of negotiations and to accept the fact that political decisions will not reflect partial, that is, exclusively national interests. ${ }^{20}$ The European Union is thus premised upon a model of political (and social) engagement with dynamic learning in action.

The same model applies horizontally; namely, to interactions among European citizens and other collective actors. Citizens and administrative authorities throughout the EU, for instance, have realised that the old fashioned notions of 'immigrant', 'resident alien' and 'temporary guest' do not apply to Community nationals. ${ }^{21}$ The latter not only are Union citizens, but they are also encouraged to participate in a wide range of associative relations beyond national borders and to choose their civic home. Member States must refrain from imposing any obstacles to the exercise of the fundamental freedoms and any other restriction which might render it ineffective or make it less attractive. ${ }^{22}$ In light of the above considerations, it may well be the case that the novelty of European citizenship lies precisely in its capacity to change our understanding of community and to make the boundaries of membership more open and flexible. Viewing European citizenship as a mere rational superimposition on deeply rooted national identities underestimates this. By allowing too much for deeply embedded national identities, it has misjudged the extent to which European integration has turned Europeans into Union citizens and has fostered a cosmopolitan orientation of openness towards the 'other' (i.e., Community

\footnotetext{
${ }^{20}$ Kostakopoulou, 'Towards a Theory of Constructive Citizenship in Europe', (1996) 4(4) Journal of Political Philosophy 337.

${ }^{21}$ Plender, 'An Incipient Form of European Identity', in F. Jacobs (ed.), European Law and the Individual (North Holland, 1976); Poiares Maduro, We the Court: The European Court of Justice and the European Economic Constitution (Hart Publishing, 1998);Guild, Elements of a European Identity (Kluwer, 2004).

${ }^{22}$ On non-discriminatory restrictions, see Daniele, 'Non-Discriminatory Restrictions to the Free Movement of Persons', (1997) 22 ELRev 191; Castro Oliviera, 'Workers and Other Persons: Step by Step from Movement to Citizenship -Caselaw 1995-2001', (2002) 39 CMLRev 77; Toner, Partnership Rights, Free Movement and EC Law (Hart Publishing, 2004), chap. 6.
} 
nationals and their family members). But does this mean that European Union citizenship is a type of cosmopolitan citizenship? ${ }^{23}$

Without a doubt, cosmopolitanism is hard to define. Echoing the universalism of the stoic tradition, cosmopolitanism unties the citizen from the bounds of a particular polity. Cosmopolitanism thus entails an outward orientation: citizens' special duties towards their compatriots and resident non-compatriots do not exhaust their obligations. For they owe duties of respect and justice to all persons in the world and have an obligation to recognise the value of universal standards of moral conduct and judgement. Owing to the ethical nature of the above prescriptions, moral cosmopolitanism is distinguished from political cosmopolitanism, that is, the institutional design of, and commitment to, a political order that transcends the nation-state. ${ }^{24}$ But the moral/political distinction does not capture all variants of cosmopolitanism. Not only there exist several intermediate positions on the moral/political cosmopolitanism continuum, but there is also a variety of cosmopolitan perspectives within each of these seemingly antithetical positions. O’Neil's agenda for transnational justice, Beitz's emphasis on international redistributive justice, Singer and Sue’s arguments about basic rights, famine and affluence and Barry's international redistributive taxation proposal are just a few examples of moral cosmopolitanism. At a more general level, Kantian, neo-Kantian and utilitarian perspectives attest the divergence in both theoretical premises and substantive applications of moral cosmopolitanism. Notwithstanding their differences, however, all the above mentioned

\footnotetext{
${ }^{23}$ According to Held (1995), cosmopolitan citizenship is associated with the development of an orientation of openness to other citizens, societies and cultures across the globe; Democracy and the Global Order (Polity: 1995). See also Held, Cosmopolitanism: A Defence (Polity: 2006). John Urry refers to a capacity to look beyond the limited horizons of the particular context; 'Globalisation and Citizenship', paper given to World Congress of Sociology, Montreal, July 1998 (http://www.comp.lancs.ac.uk/sociology/009ju.html). Compare also Shaw, 'The Emergence of Postnational Constitutionalism in the European Union', (1999) 6 Journal of European Public Policy 579 and Chalmers, 'Postnationalism and the Quest for Constitutional Substitutes', (2000) 27 Journal of Law and Society 178.

${ }^{24}$ See, for example, Pogge’s work; 'An Egalitarian Law of Peoples:, (1994) 23 Philosophy and Public Affairs 195, World Poverty and Human Rights: Cosmopolitan Responsibilities and Reforms (Polity, 2002).Sometimes a distinction is drawn between moral and institutional cosmopolitanism; on this, see Brock and Brighouse (eds), the Political Philosophy of Cosmopolitanism (Cambridge University Press, 2005)
} 
perspectives converge on the idea that citizens' obligations are not confined within territorial states and that the boundaries of justice do not coincide with states’ borders. ${ }^{25}$

While some approaches prescribe a transformation of both nation-state paradigm and interstate relations, there exist weaker forms of moral cosmopolitanism which do not challenge to nation-state paradigm. More specifically, it has been suggested that an orientation towards global concerns and a commitment to global distributive justice could be compatible with the existence of bounded communities and the doctrine of liberal nationalism. Tan has argued, for instance, that the idea of co-national partiality entailed by liberal nationalism, that is, the belief that a liberal democratic state must give priority to the claims of nationals and direct its cultural and material resources in order to protect the common societal culture, is not necessarily antithetical to the ideal of global equal concern. ${ }^{26}$ Drawing on Scheffler's distinction between cultural cosmopolitanism and cosmopolitanism about justice, ${ }^{27}$ Tan has observed that although liberal nationalists would have to reject the idea of culturally mobile and rootless individuals, there exists no a priori reason as to why they should reject 'cosmopolitanism about justice'. ${ }^{28}$ On this view, nation-states can legitimately privilege co-nationals' access to cultural and material resources in so far as they take appropriate action to ensure that there exists a background global economic and political context that approximates the ideal of equal opportunity. In other words, liberal nationalists can reject cultural cosmopolitanism while embracing a cosmopolitan conception of justice which makes nationality and national boundaries weightless for the distribution of material goods and resources. This view is consonant with Amy Gutman's emphasis on instilling in people awareness about global inequality and their obligations to

\footnotetext{
${ }^{25}$ Recognising that citizens owe duties to all human beings does by no means mean that they owe the same duties to everybody.

${ }^{26}$ Tan, Justice without Borders (Cambridge University Press, 2004); 'Boundary Making and Equal Concern' in C. Barry and T. Pogge (eds), Global Institutions and Responsibilities (Blackwell, 2005), pp. 48-64.

${ }^{27}$ Scheffler, 'Conceptions of Cosmopolitanism', (1999) 11(3) Utilitas 255.

${ }^{28}$ Tan, loc cit, n 25, 2005, 54-55.
} 
humanity at large as part of a programme of education for democratic citizenship. ${ }^{29}$ By cultivating a moral cosmopolitan orientation, nation-state centred citizenship can thus be made compatible duties towards strangers, thereby channelling their action towards promoting international fairness. On Gutman and Tan's accounts, liberal nationalism can become a vehicle for the promotion of cosmopolitanism, provided that citizens are enlightened and pursue their interests and goals without disregarding the plight of people outside their borders.

Having a cosmopolitan outlook thus becomes a desirable attitude and a citizenly obligation. It accurately reflects the emergence of a 'globally oriented national citizenship' ${ }^{30}$ not of a 'global citizenship'. As Parekh has observed, 'the "we" that constitutes and defines a political community is expanding to encompass those hitherto perceived as "they", and the moral gap between general duties and special duties, between those to human beings in general and to our fellow-citizens is beginning to narrow' ${ }^{31}$ The distinguishing characteristic of this approach is the reconfiguration of cosmopolitanism from a nation-state transcending phenomenon to a nationstate sustaining discourse. By making cosmopolitanism a part of the project of good citizenship, the nation-state remains the primary actor and the main locus of community.

If this reasoning is then applied to European citizenship, one could argue that the latter instils a cosmopolitan consciousness within national citizenship, without threatening to replace it. Since European citizenship is derivative of and supplementary to national citizenship, individuals' belonging to particular political homes could be complemented with a cosmopolitan orientation and a desire to enter into associative relations with other EC nationals. But if one examines more closely the conception of European citizenship as a form of (moral) cosmopolitan citizenship, (s)he will discern that it is compatible not only with liberal nationalist assumptions, but also with the seemingly antithetical, minimalist approaches to European citizenship discussed

\footnotetext{
${ }^{29}$ Gutman, 'Democratic Citizenship', in Cohen (ed), For Love of Country: Debating the Limits of Patriotism (Beacon Press, 1996), 66-71.

${ }^{30}$ Parekh, 'Cosmopolitanism and Global Citizenship', (2003) 29 Review of International Studies 3.

${ }^{31}$ Ibid, 3-17.
} 
in the previous section. Yet its advantages should not be underestimated: a) it appears to combine the strengths of liberal nationalism (i.e, the importance and value of the national context) and cosmopolitanism (openness towards the other and a reflexive attitude towards one's own perspective) without replicating their weaknesses; b) tames 'the excesses of nationalism' without celebrating rootlessness; ${ }^{32}$ and c) recognises that individuals are embedded within a national cultural context which they probably value ${ }^{33}$ without either attributing disproportionate weight on it or imposing a false sense of closure.

On this reasoning, European citizenship is neither an alternative nor rival to national citizenship. Instead, it becomes a necessary component of the latter. But this view would only be accurate if: a) European citizenship did not have a content distinct from that of national citizenship and b) did not permeate national citizenship subverting its key principles and propelling its incremental adaptation and redefinition (see section 3 below). Before elaborating on this, however, let me briefly explore the other side of the continuum, that is, political cosmopolitanism.

In general terms, political cosmopolitanism prescribes institutional arrangements that transcend the state and the principle of co-national partiality. Although there are many variants of political cosmopolitanism, three of them may be apposite to European citizenship. First, Held's conception of cosmopolitan democracy seems an attractive candidate. ${ }^{34}$ Cosmopolitan democracy is built on a project of double democratisation: the external democratisation of international politics and the democratisation of states' economy and civil society, internally. In particular, Held envisages an international community of democratic states and societies committed to

\footnotetext{
${ }^{32}$ Compare Weiler, 'European Citizenship - Identity and Differentity', in La Torre (ed), European Citizenship: An Institutional Challenge (Kluwer, 1998) pp 15-18.

${ }^{33}$ Compare, here, Nussbaum, 'Patriotism and Cosmopolitanism', in Cohen (ed), loc cit, n 29 and Tambini, 'Postnational Citizenship', (2001) 24(2) Ethnic and Racial Studies 195.

${ }^{34}$ Held, loc cit, n 23, 1995, 201-230.
} 
upholding democratic public law both within and across their own boundaries. ${ }^{35}$ He calls for an international sphere governed by a cosmopolitan democratic law which provides a high level of protection for individual and collective rights, disperses sovereignty, guarantees democratic autonomy and reserves decision-making about globally significant issues to democratically accountable global representative institutions (such as, for example, a global parliament). In the spheres of the civil society and economy too, democratisation could come about by limiting concentrations of ownership and control, the unconstrained reign of the free market and promoting critical engagement within a vibrant civil society. In Held's conception, states would have to be 'articulated with, and relocated within, an overarching cosmopolitan framework' ${ }^{36}$

Linklater has articulated a weaker form of political cosmopolitanism. This cosmopolitan perspective recommends that citizens are committed to pursuing free dialogue with others, refrain from engaging in exploitative practices and treat all human beings with compassion and care. Although the realisation of such a cosmopolitan citizenship does not depend on the formation of a post-national political community, Linklater, nevertheless, believes that his dialogue-orientated cosmopolitan citizenship is both weighty and political. ${ }^{37}$ He argues that the EU offers much hope for a cosmopolitan citizenship if only because it is characterised by the abandonment of the traditional monistic conception of sovereignty, flexibility in its orientations, attentiveness to the demands of heterogeneous publics, more inclusive membership and less controlling operations. As Linklater has remarked, 'Western Europe is the most promising site for a remarkable experiment in creating political systems which no longer weld sovereignty, territoriality,

\footnotetext{
${ }^{35}$ See also Held, Global Covenant: The Social Democratic Alternative to the Washington Consensus (Polity Press, 2004).

${ }^{36}$ Held, 'Principles of Cosmopolitan Order', in Brock and Brighouse (eds), loc cit, n 24, 10-27.

${ }^{37}$ Linklater, 'Cosmopolitan Citizenship', (1998) 21 Citizenship Studies, 23; 'Citizenship and Sovereignty in the post-Westphalian state', (1996), 2(1) European Journal of International Relations, 77. See also Dobson, 'States, Citizens and the Environment in States and Citizens', in Skinner and Strath (eds), States and Citizens (Cambridge University Press, 2003) 208-225.
} 
citizenship and shared nationality together'; 'If a neo-medieval society is to develop at all, it will most probably be between the like-minded societies of Western Europe'. ${ }^{38}$

Critics may observe, here, that Linklater’s observations about a 'new post-Westphalian era coming into existence' are a bit optimistic. They appear to exaggerate states' vulnerability to internal as well as external pressures and, in many respects, underestimate state's capacity for unexpected mutations and manoeuvres. In addition, Linklater's cosmopolitan citizenship puts more emphasis on duties, than on rights and political participation. This raises two questions: i) which agency bears the main responsibility for honouring and enforcing these obligations; and ii) why the cultivation of a sense of responsibility for the planet and its inhabitants and of a cosmopolitan ethos of solidarity and concern about human rights violations cannot be accommodated within the setting of a bounded democratic citizenship. After all, these commitments are essentially imperfect obligations.

Delanty's idea of civic cosmopolitanism bears a family resemblance to Linklater's cosmopolitanism, since it is 'rooted in a civic concept of the nation'. ${ }^{39}$ Civic cosmopolitanism is thus conceived of as a middle ground between the (false) universality of liberalism and the particularist orientation of communitarianism. By providing space for both the polis (i.e., the community) and cosmos (the world) and an institutional framework for multileveled governance beyond the nation-state, the European Union is viewed to be a concrete manifestation of civic cosmopolitanism. This is because the EU neither requires the transcendence of the nation-state paradigm nor anticipates the formation of a world community. Instead, it instantiates a polyarchic order, in which communities formed at supranational, trans-state, state and sub-state levels interact, partially constitute each other and undergo transformation as a result. European integration thus enables the formation of 'self critical identities', which transcend the dichotomy

\footnotetext{
${ }^{38}$ Linklater, loc cit, n 36, 1996, 66.

${ }^{39}$ Delanty, Citizenship in a Global Age (Open University Press, 2000).
} 
between the self and the other. ${ }^{40}$ Such a reflexive European identity could provide a cultural basis to postnational citizenship. Like Linklater, Delanty views cosmopolitan citizenship as a transnational institution. Far from being antithetical, the 'nation' and cosmopolitanism thus appear to be mutually reinforcing.

Strange though it might seem, there exist some important affinities between the cosmopolitan perspectives examined above and the Westphalian perspectives discussed in the previous section. First, both conclude that cosmopolitanism is ultimately possible in the context of the state and within the national imaginary. Because cosmopolitanism is tied to transnationalism, ${ }^{41}$ European citizenship is reduced to a type of transnational citizenship, which does not negate national citizenship. But the reduction of European citizenship to a transnational citizenship downplays both the resourcefulness of EU citizenship and the supranational character of EU law (see section 4 below). Above all, it conceals the extent to which European citizenship penetrates and subverts national citizenship, thereby triggering off tensions, institutional displacement and the incremental transformation of domestic structures and practices in ways that had not been anticipated. This is the main focus of the discussion in the subsequent section.

\section{THE ART OF THE IMPOSSIBLE}

In the past, citizenship denoted the relationship between the individual and the territorial nationstate. The European Union has changed this. Even sceptics would have to concede that the reality of 'multiple membership in various overlapping and interlocking communities formed on various

\footnotetext{
${ }^{40}$ Ibid, 140.

${ }^{41}$ I should note, here, that radical pluralists, such as Falk and Walker, put more emphasis on transnational democratic intervention by grass roots political organisations and on participatory politics. Instead of emphasising global and supranational institutional designs, their cosmopolitanism is based on political action from below and the formation of new global political cultures; Walker, One World, Many Worlds: Struggles for Just World Peace (Lynne Reiner, 1988); Falk, On Humane Governance (Polity, 1995).
} 
levels of governance, ${ }^{42}$ cannot but have important implications for citizenship theory and practice. However, multilevel governance and the fact of multiple membership, cannot by themselves, fully account for the transformative dynamic entailed by Union citizenship. For, as noted above, if European citizenship is seen as just another web of relations within which national citizens are entangled and an additional source of rights, then it could easily be reduced to a type of cosmopolitan, transnational citizenship, which complements, but does not subvert, national citizenship.

I would suggest that the novelty, and in many respects the challenge, of the European citizenship design does not lie simply in the emergence of 'nested' citizenships (supranational, national, sub-national citizenships) and institutional pluralism. More significant is the interaction between 'old' (national) and 'new' (European) citizenships and the ensuing process of incremental, transformative change. European legal and political dynamics subvert the fundamental premises of the nationality model of citizenship and change the organisational logic and practices of national citizenship. In what follows, I wish to highlight the impact of European citizenship on national political systems, which is far more extensive than portrayed by the literature, and the visionary ideas entailed by this institution. European Union citizenship is, in many respects, an institutional as well as a conceptual challenge. The latter refers to the facts that European citizenship has probed the unspoken limits of national statist citizenship and has opened up ways for redefining political community, rethinking membership, and reconfiguring citizenship. As Meehan has put it, the importance of European citizenship lays not so much in what it is, but in what it should or might be. ${ }^{43}$

\section{A Changing the boundaries of national citizenship}

\footnotetext{
${ }^{42}$ Meehan, loc. cit, n 18, 1993. Eder and Giesen (eds), European Citizenship, National Legacies and Transnational Projects (Oxford University Press, 2001).

${ }^{43}$ Meehan, 'Political Pluralism and European Citizenship', in Lehning and Weale (eds), Citizenship,

Democracy and Justice in the New Europe (Routledge, 1997).
} 
European Union citizenship does not mirror national citizenship. Whereas the latter still denotes full membership in national community, European citizenship was associated with internal mobility of labour and the creation of an internal market. Progressively, it reflected concerns about how new economic institutions and experiments could become more anchored in concrete communities and the transformation of the single market into a People's Europe. The Treaty on European Union (TEU) tied the Community law rights of free movement and residence to the political status of the citizen of the Union, thereby contributing to a 'conceptual metamorphosis' of the former. ${ }^{44}$ Accordingly, Union citizenship carries within it the expectation of equal treatment throughout the EU, irrespective of nationality. ${ }^{45}$

True, this process is riddled with fundamental ambiguities, contradictions, and tensions. The opposing dynamics between intergovernmentalism and supranationalism have not only shaped the development of Community's discourse and policy on citizenship, but are also present within the crystallised institution of Union Citizenship. The restrictive personal scope of Union citizenship, for instance, is a reflection of intergovernmentalism. Equally, the weakening of traditional state prerogatives with regard to the entry and residence of economically active or economically self-sufficient Community nationals has been accompanied by the reinforcement of the dichotomy of citizens and 'aliens', be they resident third country nationals, migrants, asylum seekers and refugees. ${ }^{46}$ Processes of equalisation thus co-exist with processes of exclusion, and the relativisation of the Member States' borders is accompanied by the reinforcement of the external frontiers of the Union and the relocation of migration controls in third countries. Although it is only right and proper that we should be reminded of this, it is difficult not to be impressed by the extent to which Community rights’ jurisprudence has transformed immigration

\footnotetext{
${ }^{44}$ See the Commission's Report on Citizenship of the Union, COM (93) 702 Final.

45 Advocate General Leger's Opinion in Case C-1214/94 Boukalfa v Federal Republic of Germany [1996] ECR I-2253.

${ }^{46}$ Baldwin-Edwards, 'The emerging European immigration regime: some reflections on implications for southern Europe’, (1997) 35(4) Journal of Common Market Studies 407.
} 
law and practice in the Member states. Nor must we lose sight of the possibility that the demands of European integration may induce further relaxation of established nationality law principles. ${ }^{47}$

The notion of 'immigrant' or 'temporary guest' has been replaced by that of Union citizen. ${ }^{48}$ Accordingly, the presence in the territory of a host Member State (MS) of Community workers, work-seekers, establishers, service-providers and tourists, as potential recipients of services, is no longer a matter of state toleration and consent. It is, instead, an issue of exercising fundamental rights. In the pre-Maastricht era, formal rights of free movement and residence were also conferred on the economically independent, retired persons, students and their families, provided that they have sufficient resources to avoid becoming a burden on the social assistance system of the host state and are covered by health insurance. ${ }^{49}$ In the post-Maastricht era, the institution of Union citizenship raised citizens' expectations ${ }^{50}$ and created a normative template for calling into question the link between citizen status and economic activity or self-sufficiency. Indeed, in its Communication to the EP and the Council on the follow-up to the recommendations of the High-Level Panel on the Free Movement of Persons, the Commission stated that 'free movement rights are becoming an integral part of the legal heritage of every citizen of the European Union an should be formalized in a common corpus of legislation to harmonise the legal status of all Community citizens in the MS, irrespective of whether they pursue a gainful activity or not'. ${ }^{51}$

The ECJ did not hesitate to embark upon a constructivist reading of Union citizenship. In Martinez Sala, the ECJ held that lawful residence of a Community national in another MS is

\footnotetext{
${ }^{47}$ On this, see Gerard-Rene De Groot, 'Towards a European Nationality Law’, in Hildegard Schneider (ed.), Migration, Integration and Citizenship (Maastricht, 2005); Closa, 'Citizenship of the Union and nationality of the Member States', in O'Keeffe and Twomey (eds), Legal Issues of the Maastricht Treaty (Wiley, 1997) 109.

${ }^{48}$ Bohning, The Migration of Workers in the United Kingdom and the European Community' (Oxford University Press, 1992) 18-19. See also Wilkinson, ‘Towards European Citizenship?’, (1995) 1(3) European Public Law 417.

${ }^{49}$ Council Directives 90/364 [OJ 1990 L 180/26], 90/365 [OJ 1990 L180/30], 90/366 replaced by Dir. 93/96 EEC [OJ 1993 L 317/59].

${ }^{50}$ European Commission, Second report on Citizenship of the Union, COM (97) 0230.

${ }^{51}$ COM (98) 0403 final.
} 
sufficient to bring her within the scope of ratione personae of the provisions of the Treaty on European citizenship. Since Sala had been authorised to reside in Germany, the requirement of the 1985 Federal Law that a Community national had to produce a residence permit in order to receive a child-raising allowance, when that state's own nationals were not required to produce any document of that kind, amounted to unequal treatment prohibited by Article 12 EC. In other words, Sala was entitled to receive non-discriminatory treatment on the grounds of nationality as a European citizen lawfully residing in another Member State. By putting 'flesh on the bones of European Union Citizenship', the Court displayed its capacity to attach a new constructive meaning to the status of citizenship of the Union, thereby overriding the interests of Member States. ${ }^{52}$ More importantly, it did so by calling into question the link between the existence of citizen status and economic activity or self-sufficiency. ${ }^{53}$ In Elsen the Court highlighted further the importance of Union citizenship, ${ }^{54}$ by ruling that, although MS retain the power to organise their social security schemes, they must, nonetheless, comply with Community law and the Treaty provisions on Union citizenship.

In 2001 the ECJ continued to strengthen citizens’ rights. The political climate was favourable for constructive interpretations of Union citizenship owing to the adoption of the EU Charter of Fundamental Rights in Nice (7 December 2000) ${ }^{55}$ and the Commission's proposal for a Directive on the right of citizens and their family members to move and to reside freely within the territory of the MS. ${ }^{56}$ The draft directive, which explicitly referred to the 'new legal and political environment established by citizenship of the Union', 57 suggested a 'phased' approach to the disentanglement of residence form economic activity, whereby non-active economic actors would have to satisfy the self-sufficiency and possession of sickness insurance conditions in the

\footnotetext{
${ }^{52}$ S. O’Leary, 'Putting Flesh on the Bones of European Union Citizenship' (1999) 24 European Law Review 68-79.

${ }^{53}$ As the Advocate General stated, 'the limitations in Article 8a itself concern the actual exercise but not the existence of the right'; Case C-85/96 at para 18.

${ }^{54}$ Case C-135/99 Ursula Elsen v Bundesversicherungsanstalt fur Angestellte, Judgment of the Court of 23 November 2000.
} 
first four years of residence in the host state. Thereafter, non-active economic actors would enjoy a permanent and unqualified right of residence and 'virtually complete equality of treatment' ${ }^{58}$ Permanent residence would thus entail security of residence by providing immunity from expulsion and access to social welfare in the host MS. ${ }^{59}$

Capitalising on this climate, in Grzelczyk Advocate General Alber stated that: 'Citizenship of the Union took on greater significance, in contrast to the perception of individuals as purely economic actors which had underlain the EC Treaty. The conditions on which freedom of movement may depend are now no longer economic in nature, as they still were in the 1990 directives. The only 'limitations and conditions' attached to freedom of movement now are imposed on grounds of public policy, public security and public health' ${ }^{60}$

Grzelczyk, a French national studying physical education in Belgium, who during his first three years of his study had supported himself through various jobs, applied to the CPAS for payment of minimex, a minimum subsistence allowance paid in Belgium. This would enable him to complete his university studies. CPAS granted Grzelczyk the minimex. However, when the CPAS applied to the Belgian state authorities for reimbursement of the payments, the application was declined on the ground that Grzelczyk was not a Belgian national. Mr Grzelczyk challenged this refusal before a Labour tribunal. Rejecting the minimalist perspective associated with the model of market citizenship (section 1), the ECJ stated that 'Union citizenship is destined to be a fundamental status of nationals of the MS, enabling those who find themselves in the same situation to enjoy the same treatment in law irrespective of their nationality, subject to such exceptions as are expressly provided for' ${ }^{61}$ Since Union citizens can rely on Article 12 EC in all

\footnotetext{
${ }^{55}$ [2000] OJ C364.

${ }^{56}$ COM (2001)257 Final; Brussels 23.5.2001.

${ }^{57}$ COM (2001) 257 final, para 1.3 of the explanatory memorandum.

${ }^{58}$ Ibid Article 14.

${ }^{59}$ Ibid Articles 26 and 21(1).

${ }^{60}$ Case C-184/99 [2001] ECR I-6913 at para. 52.

${ }^{61}$ Grzelczyk, above n 84 at para 31. Under the Commission's proposed directive, on completion of a fouryear educational course in a MS, the self-sufficiency conditions attached on the residence of students would
} 
situations that fall within the material scope of the EC Treaty (Sala), Article 12 EC, read in conjunction with Union citizenship, led the Court to rule that students studying in another MS and facing temporary economic difficulties can rely on the non-discrimination clause in claiming social advantages. Indeed, it can be argued that a certain degree of financial solidarity between nationals of a host MS and nationals of other MS must be recognised, particularly in cases of temporary economic difficulties. In such cases, beneficiaries would not be an 'unreasonable' burden on the host MS.

Grzelczyk gave the Court the opportunity to advance the normative debate on the meaning and implications of Union citizenship, by calling into question the link between economic activity and residence in certain circumstances (i.e., temporary economic difficulties). This gave 'a strong appearance of case law moving away from the grant of particular rights to particular groups of (economic) actors and instead embracing a powerful mission of protection of individual rights'. ${ }^{62}$ By so doing, it initiated a wider learning process, since students who face temporary economic difficulties would have to be seen as associates and 'belongers' to the host community, rather than as strangers and a problem. This was re-affirmed in the Bidar case in 2005. ${ }^{63}$ In Bidar, the Court departed from earlier case law which excluded students from the grant social assistance, by ruling that, as Union citizens, students who have demonstrated 'a certain degree of integration into the society of the host state' can claim maintenance grants. But the Member States are also entitled to ensure that 'the grant of assistance does not become an unreasonable burden'. Even though the requirement of demonstrating 'a certain degree of integration' is not sufficiently clear, the Court has, nevertheless, indicated that a reasonable

cease to apply, thereby enabling former students to stay on in the host state and to receive social security entitlements on the same basis as nationals (Articles 7 and 8(4)).

${ }^{62}$ S. Weatherill, Cases and Materials on EU Law (Oxford: Oxford University Press, 2003) 490.

${ }^{63}$ Case C-209/03, Bidar v London Borough of Ealing, Judgment of 15 March 2005. For a critical view, see M. Dougan, 'Fees, Grants, Loans and Dole Cheques: Who covers the Cost of Migrant Education within the EU?’, (2005) 42 Common Market Law Review 943-986. 
period of lawful residence ${ }^{64}$ and the ensuing immersion in a web of interactions in the host state ${ }^{65}$ generates an entitlement to non-discrimination. Departing from existing case law, the Court thus ruled in Trojani that a lawfully resident non active economic actor is entitled to a social assistance benefit on the basis of Article $12 \mathrm{EC},{ }^{66}$ whereas in Collins, the absence of a genuine link between a jobseeker and the employment market of the host state invalidates an entitlement to a jobseeker's allowance. ${ }^{67}$ In both cases, however, the principle of proportionality must be respected and the application of a residence requirement is open to judicial review.

In Baumbast, the Court went beyond the predictive confines of settled law in order to bring about institutional change. It did not only derive a new right of residence for a parent who is the primary carer of a child studying in a host MS (Article 12 of Council Reg. 1612/68), but it also ruled that Article 18(1) EC has created directly effective rights enforceable in national courts. ${ }^{68}$ Although the German and UK Governments submitted that Article 18 (1) did not create a directly effective right because it was not intended to be a free-standing provision, the ECJ relied on the normative weight of Union citizenship, and ruled that:

'...As regards, in particular, the right to reside within the territory of the Member States under Article 18(1) EC, that right is conferred directly on every citizen of the Union by a clear and precise provision of the EC Treaty. Purely as a national of a Member State, and consequently as a citizen of the Union, $\mathrm{Mr}$ Baumbast therefore has the right to rely on Article 18(1) EC’.

Any limitations and conditions imposed on that right must be applied in compliance with the limits imposed by Community law and in accordance with the general principles of that law,

\footnotetext{
${ }^{64}$ Ibid. See also Case C-456/02 Trojani v CPAS [2004] ECR I-7573, para 43. The ECJ refers to ' lawful residence in the host MS for a certain time or the possession of a residence permit'.

${ }^{65}$ Bidar had completed his secondary education in the UK; note 34 above.

${ }^{66}$ Ibid.

${ }^{67}$ C-138/02 Brian Francis Collins [2004] ECR I-2703. Similarly, the taking up of residence abroad is not a satisfactory indicator of a loss of connection with one's home Member State which is demonstrating its solidarity with the applicant by granting a civilian war benefit to him/her; Case C-192/05, K. Tas-Hagen and R.A. Tas, Judgement of the Court of 26 October 2006.

${ }^{68}$ Case C-413/99 Baumbast, $R$ v Secretary of State for the Home Department, Judgement of the Court of 17 September 2002.
} 
in particular the principle of proportionality. ${ }^{69}$ As such, they 'do not prevent the provisions of Article 18(1) EC from conferring on individuals rights which are enforceable by them and which the national courts must protect'. Such an interpretation further weakened the link between economic status and the right to free movement and reflected broader normative aspirations for a constructive understanding of European citizenship that eventually found their way into juridicopolitical reform ten years after the establishment of this institution. Building on the rightsbased approach characterizing the jurisprudence on the free movement of workers, the Citizenship directive (Dir. 2004/38) established an unconditional right of permanent residence for Union citizens and their families, after a period of five years of continuous legal residence in the territory of the host MS, which creates an entitlement to equal treatment in the areas covered by the Treaty.

Notwithstanding the language of universality and the transformative impact of Union citizenship, however, we should not lose sight of the institutional and structural conditions that underpin the distribution and exercise of citizenship rights. Union citizenship may have been presented as a 'de-gendered', 'de-raced' and 'classless' concept, but, in reality, its scope reflects gender, race and class differentials; it excludes long-term resident third country nationals and limits the rights of residence of non-active economic actors who are not self-sufficient and wish to reside in another Member State for more than three months, ${ }^{70}$ be they women engaging in domestic work and care for dependent relatives, unemployed people, or persons who have not acquired the necessary skills due to institutionalised racial discrimination in education and labour markets. In addition, differential levels of protection against racial discrimination in national legislations often function as a disincentive for the cross-border movement of ethnic migrant citizens.

\footnotetext{
${ }^{69}$ On the proportionality assessment, see M. Dougan, 'The Constitutional Dimension of the case law on Union citizenship', (2006) 5 European Law Review 613-641.

${ }^{70}$ See the typology of residence rights entailed by the Directive 2004/38.
} 
Nevertheless, European citizenship should not be regarded as a finished institution. Its content is flexible and dynamic. For instance, the ECJ did not hesitate to establish a right of residence for mothers who are the primary carers of children who entitled to reside in a MS because they are either Union citizens or enrolled on educational establishments. ${ }^{71}$ In Carpenter the Court displayed a truly innovative approach by drawing a derivative right of residence from a Treaty article (Article 49 EC), thereby overriding restrictive national immigration rules. ${ }^{72}$ Mrs Carpenter, a national of the Philippines and the spouse of a UK national, challenged the deportation order issued by the Home Secretary. She claimed a right of residence in the UK on the grounds that her deportation would impede her husband's right to provide and receive services in other Member States, since she was looking after his children from his first marriage. The UK authorities maintained that, since Mr Carpenter was a national of the UK living in the UK, the cross-border dimension required under Community law was absent. But the Court did not agree with the UK Government's submission. ${ }^{73}$ Mr Carpenter was carrying out a significant proportion of his business abroad, thereby activating his right to provide services enshrined in Article 49 EC. The latter 'could not be fully effective if Mr Carpenter were to be deterred from exercising it by obstacles raised in his country of origin relating to the entry and residence of his spouse'. ${ }^{74}$ Article 49 EC read in light of the principle of respect for family life, which is recognised by Community law, ${ }^{75}$ must thus be interpreted as precluding Carpenter's deportation. $^{76}$

In $M R A X$, the Court had an opportunity to take issue with strict interpretations of the visa requirement for third country national spouses and the ensuing restrictive practices adopted by the Belgian state, and to highlight that the residence rights of such persons do not derive from states'

\footnotetext{
${ }^{71}$ See Chen (loc cit, n 21) and Baumbast (loc cit, n 52) respectively.

${ }^{72}$ G. Barret, 'Family Matters: European Community Law and Third Country Family Members' (2003) 40 Common Market Law Review 369-421, 406.

${ }_{74}^{73}$ Case C-60/00 M. Carpenter, Judgment of the Court of 11 July 2002, paras. 28-30.

${ }^{74}$ Ibid at para 39.

${ }^{75}$ On this, see the provisions of the Council Regulations and directives on the free movement of employed and self-employed persons as well as Article 8 ECHR.

${ }^{76}$ Carpenter's deportation could not be justified on public order or safety grounds.
} 
authorization of their entry. ${ }^{77}$ Instead, they are based on their family ties with Union citizens. In this respect, the extensive rights which Community workers and their families enjoy by virtue of Community law have not only ruptured conventional understandings of citizenship, but they have also set an important precedent for third country nationals and other excluded groups. Directive 2004/38 has strengthened citizens' rights. True, even though the 'fundamental and personal right of residence is conferred directly on Union citizens by the Treaty', for periods of residence exceeding three months, Member States may require Union citizens to register with the competent of authorities for the issuing of a registration certificate or a residence card. But a failure to comply with such formalities can never constitute a ground for deportation. As long as the beneficiaries of the right of residence do not become an unreasonable burden on the social assistance system of the host MS they should not be expelled. If they have to rely on such assistance, the MS concerned has to take into account a number of considerations, such as the temporary nature of their difficulties, the duration of their residence, the personal circumstances and the amount of aid granted before deciding to adopt an expulsion measure. And it is explicitly stated that an expulsion measure should not be adopted against workers, self-employed persons or job-seekers, who can provide evidence that they actively seek employment and that they have a genuine change of being engaged, save on grounds of public policy or public security.

Member states may restrict the freedoms of movement and residence of Union citizens and their family members on the basis of the above mentioned grounds, but as the ECJ has consistently stated, the latter must be strictly interpreted and comply with the principle of

\footnotetext{
${ }^{77}$ Case C-459/99, Judgment of the Court of 25 July 2002. In this case, the Movement Against Racism, Anti-Semitism and Xenophobia ASBL (Mouvement contre le racism, l'antisemitisme et la xenophobie ASBL, (MRAX)) challenged the legality of a Circular of the Ministers for the Interior and Justice of 28 August 1997 on the grounds that it contravened the Community directives on the movement and residence and the principle of respect for family life, which is protected by Community law. Drawing on Carpenter, the ECJ emphasised the importance of ensuring protection of the family life of Community nationals. It ruled that a number of state practices, such as sending back to the border third country national spouses of Community nationals who do not possess the necessary entry documents (i.e., an identity document or visa), denying them a residence permit or ordering an expulsion order on the grounds that they were 'illegal' entrants or residents, are disproportionate and unlawful under Community law.
} 
proportionality. ${ }^{78}$ Nor can these grounds be invoked by a MS in order to serve economic ends. Measures taken on these grounds, that is, decisions denying leave to enter or ordering expulsion, shall be based exclusively on the personal conduct of the individual concerned, which must constitute 'a genuine and sufficiently serious threat to the requirements of public policy affecting one of the fundamental interests of society' ${ }^{79}$ The same assessment must take place with respect to third country nationals who are spouses of Community nationals, for whom alerts have entered in the Schengen Information System for the purpose of refusing them entry. In commenting on the relationship between the Schengen Implementing Convention and the Community law provisions on freedom of movement for persons, the ECJ has stated that both the Member State issuing an alert and the Member State that consults the Schengen Information System state must first establish that the presence of a person constitutes a genuine, present and sufficiently serious threat affecting one of the fundamental interests of society. ${ }^{80}$ Clearly, a member state cannot order the expulsion of a Union citizen as a deterrent or a general preventive action. Previous criminal convictions cannot in themselves constitute grounds for deportation, but past conduct may constitute evidence of a present threat to public policy, particularly if the individual concerned is likely to reoffend. By insisting on a strict interpretation of the public policy derogations, the ECJ has circumscribed significantly the Member States' discretionary power over nationals from other Member States. By so doing, it has reduced the risk of possible 'scapegoating' of 'foreigners' in order to satisfy public opinion. Yet national administrative practices forcibly deporting Union citizens by reason of an enforceable criminal conviction continue to take place, even though they clearly breach Community law. According to Advocate General Stix-Hackl, 'the German practice of automatic deportation, without regard for personal circumstances, justified on the ground of its deterrent effect on other foreigners and in breach of

\footnotetext{
${ }^{78}$ Case C-100/01 Ministre de l'Interieur v Aitor Oteiza Olazabal, Judgement of the Court of 26 November 2002; Joined Cases C-482/01 and C-493/01 Orfanopoulos v Land Baden-Wurttemberg [2004] ECR I-5257. ${ }^{79}$ Case 30/77 R v Bouchereau [1977] ECR 1999.

${ }^{80}$ Case C-503/03 Commission v Kingdom of Spain, Judgement of the Court of 31 January 2006.
} 
the fundamental right to family life breaches Community law' ${ }^{81}$ The new citizenship directive goes a step further in the direction of enhancing security of residence for Union citizens by requiring Member States to take into account a number of considerations, such as, the length of one's residence, his/her age, state of health, family and economic situation, social and cultural integration and the extent of his/her links with the country or origin before taking an expulsion decision and by stipulating that the residence of Union citizens or their family members can only be terminated on serious grounds of public policy or public security. ${ }^{82}$ In addition, long-term resident Union citizens and minors may not be ordered to leave the territory of a Member State, except on imperative grounds of public security. ${ }^{83}$

Another major area illustrating the authoritative transformation of domestic citizenship and migration laws concerns the wide range of substantive rights that Union citizens and their family members enjoy in the host MS. Community law prohibits discrimination based on nationality as regards access to employment, remuneration and other conditions of work, and the enjoyment of social and tax advantages, housing, equal access to vocational schools and retraining centres and participation in trade unions and staff associations. Interestingly, the enjoyment of these rights does not depend on a transfer of loyalty to the host MS. Nor is the length of residence or of employment a prerequisite for qualifying for a social advantage in the host state, as this depends on an individual's worker or resident status. Family members of Community workers, ${ }^{84}$ have the right to install themselves with the primary beneficiary, enjoy security of residence and to take up employment or self-employment in the host $\mathrm{MS}^{85}$ In addition, the children of EU-national workers are entitled to be admitted to the host state's

\footnotetext{
${ }^{81}$ See the Advocate General's Opinion in Case C-441/02 Commission v Federal Republic of Germany, 2 June 2005.

${ }^{82}$ Article 28(1) of Directive 2004/38.

${ }^{83}$ Article 28(3) of Directive 2004/38.

${ }^{84}$ They include the spouse, the registered partner, if the legislation of the host Member State treats registered partnership as equivalent to marriage, descendants who are either under the age of 21 or dependent, and those of the spouse or partner and depending relatives in the ascending line; see Art. 2 of Directive 2004/38.

${ }^{85}$ See the Court's recent Judgement in Case C-10/05 Mattern and Cikotic, 30 March 2006.
} 
educational courses under the same conditions as nationals of that state, including to the primary and secondary schooling system, and to receive educational grants and assistance. ${ }^{86}$ According to Article 24 of directive 2004/38, Union citizens who have a right of permanent residence in a Member state and their family members shall enjoy equal treatment with the nationals of that Member State within the scope of the Treaty. But prior to the acquisition of the right of permanent residence, the Member states are entitled to decide whether they will grant social assistance during the first three months of residence, or for a longer period, and whether they will 'grant maintenance aid for studies, including vocational training, consisting in student grants or student loans to persons other than workers, self-employed persons, persons who retain such status and members of their families'. ${ }^{87}$ This means that work seekers during the above mentioned period might be able to claim social assistance provided that they do not become an unreasonable burden on the public finances of the host MS. They could, for example, receive financial support designed to facilitate access to employment, such as a job-seeker's allowance, if the claimant has been habitually resident there, thereby having acquired a 'genuine link' with the employment market in question ${ }^{88}$, subsistence allowances and tide-over allowances in Belgium even in cases where the applicants have completed their secondary education in non-Belgian establishments. ${ }^{89}$ And students who are studying in another Member States will be able to rely on the non-discrimination clause in claiming social assistance of they face temporary economic difficulties (Grzelczyk), and will be entitled to receive financial support (either a subsidized loan or a grant) for their maintenance costs if they have established a genuine link with the society of the host state, thereby demonstrating 'certain degree of integration into the society of that state'. ${ }^{90}$

\footnotetext{
${ }^{86}$ See, for example, Joined Cases 389 and 390/87 Echternach and Moritz v Netherlands Minister for Education and Science [1989] ECR 723.

${ }^{87}$ Article 24(2) of Directive 2004/38.

${ }^{88}$ Case C-138/02 Brian Francis Collins v Secretary of State for Work and Pensions [2004] ECR I-2703.

${ }^{89}$ Case C-224/98 Marie-Nathalie D'Hoop v Ofice national de l'emploi, Judgement of the Court of 11 July 2002; Case C-258/04 Ioannis Ioannides, Judgement of the Court of 15 September 2005. Compare Case C224/02 Pusa [2004] ECR I-5763.

${ }^{90}$ Case C-209/03 The Queen (on the application of Dany Bidar) $v$ London Borough of Ealing and Secretary of State for Education and Skills, Judgment of the Court of 15 March 2005).
} 
The grant of such benefits to Union citizens clearly 'enlarges the social content of citizenship' 91 without undermining national welfare systems and attests the incremental expansion of the right to equal treatment enjoyed by Union citizens. ${ }^{92}$

Another area which demonstrates the changing boundaries of national citizenship is employment in the public service. Despite national executives' claims that 'freedom of movement was not meant to later the legal situation existing before the Communities were established as regards the organization of the state and in particular access for foreigners to the public service', ${ }^{93}$ the Court has curbed the traditional state prerogative of identifying the boundaries of its public sector and excluding non-nationals from access to it. Employment in the public sector can thus no longer be confined to nationals who are deemed to have 'a relationship of special allegiance to the state and can identify with its interests'. There is an exception for posts involving direct or indirect participation in the exercise of powers conferred by public law and for duties designed to safeguard the interests of the state. This exception therefore does not apply to posts that come under the state or other public organizations but are too remote from the specific activities of the public service or involve the exercise of power conferred by public law sporadically, thereby opening up a wide range of public service posts to Community nationals. This includes posts in public health care, state education, non-military research and public bodies involved in the provision of services.

European citizenship provisions have thus changed the boundaries of national citizenship. They have achieved this by invalidating ethnicity as a boundary marker and diluting the

\footnotetext{
${ }^{91}$ Guild, The Legal Elements of European Identity (Kluwer, 2004).

${ }^{92}$ In Pusa, Advocate General Jacobs stated that, far from being limited to a prohibition of direct or indirect discrimination, Article $18 \mathrm{EC}$ applies to non-discriminatory restrictions, including unjustified burdens - an approach that was taken up by the Court in Schempp; Case C-224/02 Pusa [2004] ECR I-5763, Case C403/03 Egon Schemmp [2005] ECR I-0000. Compare also the Opinions of AG Geelhoed and Kokott in Cases C-406/04 De Cuyper (delivered on 2 February 2006) and C-192/05 Tas-Hagen, R.A. Tas V Raadskamer WUBO van de Pensioen -en Uitkeringsraad (delivered on 18 April 2006) respectively. But the Court opted for 'an indirect discrimination approach'; Case C-406/04 De Cuyper [2006] ECR I-000; Case C-192/05 Tas-Hagen, R.A. Tas v Raadskamer WUBO van de Pensioen -en Uitkeringsraad, Judgement of the Court of 26 October 2006.

${ }^{93}$ Case 149/79 European Commission v Belgium [1980] ECR 3881, 2895.
} 
traditional link between the enjoyment of citizenship rights and the possession or acquisition of state nationality. As an institutional challenge, European citizenship has enabled Union citizens to escape the closure of territorial democracy and to enjoy a wide range of associative relations across national boundaries. But the transformative potential of European citizenship does not stop at this point. European citizenship is also a conceptual challenge; that is, it has the capacity to change our understanding of citizenship and membership with a view to opening up new forms of political community. As we shall see below, Union citizenship holds out the promise of a constructive approach to citizenship which is more respectful of 'difference' and inclusive than the nationality model of citizenship.

\section{B European citizenship: Writing the future}

The establishment of European Union citizenship has enriched the political imagination by bringing forth an alternative conception of community; namely, one that is based neither on ascriptive membership nor on the liberal notion of consent. Europe's deep diversity and the contestation surrounding its shape and future lead us to view the EU as community that is held together by the concern and willingness of its various constituent units to participate in the collective shaping of the process of European integration and in institutional design. Such a conception of community does not only allow for disagreements and conflicts, but also shows that a sense of community can be created and sustained even though its members have different views about its nature and future.

In such a constructed and flexible community, European citizenship cannot be an institutional reflection of pre-existing, pre-political views about community membership and identity. Instead, it becomes a catalyst for the formation of a civic and reflexive European identity. As Preuss has remarked, 'citizenship does not presuppose the community of which the 
citizen is a member, but creates this very community'. ${ }^{94}$ True, this perspective contradicts liberal nationalist perspectives by refusing to make the existence of a fully fledged, unified and bounded European demos the precondition of European democracy and citizenship. But its main advantage is that it accurately reflects the constructed nature of the European polity. European citizenship thus becomes a project to be realised as the 'grand conversation' about the political restructuring of Europe goes on.

Because European citizenship is seen as an issue of institutional design, it carries within it an ethical responsibility; the responsibility to be nourished by institutions, practices, rules and ideas embodying a commitment to social transformation, democratic reform and respect for the Other. In 1996 I used the term constructive citizenship in order to denote not only the constructed (as opposed to natural and objective) nature of European citizenship, but also its potential for new transformative politics beyond the nation-state. ${ }^{95}$ One crucial feature of constructive citizenship is that it postulates a vision of inclusion and equal democratic participation in a community where difference is valued and appreciated - and not simply tolerated. Such a conception of citizenship embodies a novel and more flexible conception of demos: it separates the demos from ethnic and cultural commonalities and reconfigures it as a political process of participatory enactment. It is widely acknowledged that the European demos in formation can not be built on some form of tangible homogeneity among the European peoples or on mythical foundations. ${ }^{96}$ Nor does it require some form of cultural conformity or a hegemonically imposed universalism as a requirement for admission. Rather, it can only be conceived of as a genuinely heterogeneous European public. By the latter, I mean a public that does not seek to level out differences or to

\footnotetext{
${ }^{94}$ Preuss, 'Citizenship and Identity: Aspects of a Political theory of Citizenship’, in Bellamy et al (eds), Democracy and Constitutional Culture in the Union of Europe (Lothian Foundation Press, 1995) p 108.

${ }^{95}$ Kostakopoulou, loc. cit, n 18, 1996.

${ }^{96}$ But compare Smith, loc cit, n 11, 1992.
} 
absorb other identifications and allegiances, but is committed to 'the pursuit of multiple connections of respect across persisting differences' ${ }^{97}$

This has implications for citizenship theory and practice. Although nationality has been taken to be a proxy for political community, the free movement provisions of the Treaty, coupled with the grant of local electoral rights to Community nationals in the state of their residence, have severed the link between nationality and the enjoyment of equality of treatment and rights. Interestingly, the boundaries of national citizenship have not been relaxed 'from within' as to allow Community nationals to obtain citizenship via naturalisation, but they have been 'ruptured from outside' through the conferral of rights which are enforceable before national courts. Such developments have made domicile a more suitable criterion for membership in the European demos, than possession, or acquisition, of Member State nationality.

Domicile is based on ascertaining certain factual conditions from which an intention to make a particular territory the hub of one's interests and life can be deduced. As such, it is considerably less exclusionary than the nationality principle, since it would include as participants and respected members all those who have made a particular territory their home, the centre of their economic life, pay taxes, and are affected by state policies, and participate in a whole web of social interactions which undoubtedly generate expectations. If EU citizenship were conditioned on domicile, third country nationals, who have been residing on a lawful and permanent basis in the territories of the EU for five years, would have been transformed into European citizens. Several institutional actors have campaigned long and hard for such a reform, arguing that EU citizenship needs to be disentangled from state nationality and affirm itself as a true supranational institution, if it is not to be robbed of democratic quality and substance.

Despite the inclusionary effects and normative appeal of this reform, it is true that national executives see it as an anathema. This owes much to the resilience of nationalism which

\footnotetext{
${ }^{97}$ Connolly, 'Cross-State Networks: A Response to Dallmayr', (2001) 30(2) Millennium 349. But a standard critique of cosmopolitanism has been that its tendency to view 'the 'people' as a flexible category; on this, see Hutchings, International Political theory (Sage, 1999), p 173.
} 
portrays the exclusion of non-national residents from the democratic process as a necessary counterpart to national membership. Liberal nationalism and contractarian moral theory have indeed been premised on the assumption that national societies are self-sufficient and selfenclosed schemes of social cooperation the membership of which is by and large confined to conationals. Accordingly, the exclusion of non-national residents from the rights and benefits of citizenship is seen as a necessary consequence of community's process of self-definition. But this assumption is deeply flawed. It is based on an odd circularity, whereby aliens are by definition outside the community by virtue of a prior self-definition of the community which separates 'us' and 'them', privileges 'us' over 'them' and, more importantly, screens out the various lines of connections and ties of interdependence between 'us' and 'them'. If I am correct on this, then political exclusion and the transformation of democracy into ethnarchy might not be necessary consequences of a community's right to democratic self-determination, but, instead, they may be contingent consequences of a contestable model of democracy which is rooted in the modern statist world and is, therefore, in need of correction in this millennium. The fact that Community nationals are free to choose their civic home within the European Union, have rights in the workplace and society of the host state and take part in local governments and European Parliament elections in the Member state of their residence lends credence to the above argument. Since the boundaries of the community have been extended to include nationals of other Member States, there is no a priori reason to justify the preservation of quasi-nationalist trappings on the institution of Union citizenship. And although one understands the political pressures and the intergovernmentalist logic underlying the restrictive personal scope of Union citizenship, such a compromise can only come at the expense of furthering the development of European citizenship.

From this it also follows that Community nationals' partial franchise in the Member State of their residence must be reconsidered with a view to extending their political participation to national parliamentary elections. Some might argue, here, that admission of Union citizens to the 'national community' of citizens would undermine the distinction between nationals and aliens 
and dilute the national character of parliamentary elections. Others might be quick to point out here that such a reform might undermine national interests. Although such objections are reasonable from the standpoint of liberal nationalism, they need reassessment in light of the current state of European integration and the coordinated efforts to devise a European security policy. As noted above, in the eyes of European and national laws, Community nationals are neither 'aliens' nor 'strangers' who have settled within a state 'without any interest in the country or its institutions'. ${ }^{98}$ The recent Citizenship Directive 2004/38 has given concrete form to the principle that residence generates entitlements and had added further substance to Union citizenship, by establishing an unconditional right of permanent residence for Union citizens and their families who have resided in a host Member State for a continuous period of five years. Accordingly, limiting the political rights of permanent resident Union citizens, who are already members of the demos at the local level and permanent members of the community, hinders democratic participation and deprives Community nationals of effective voice in the legislative forum.

Critics might argue, here, that Union citizens would be deprived of their right to consent to be part of national publics if they are automatically allowed to vote at national elections. However, this argument appears to overlook the fact that Union citizens are free to choose whether they will exercise their rights in the Member state of their residence, and a decision to do so would unequivocally demonstrate their consent. True, this might affect their voting rights in the Member State of their origin. But since several Member States do not permit their own nationals to vote or to stand as candidates if they reside abroad, Union citizens would welcome full enfranchisement in the Member State of their residence. The absence of political will seems to be a realistic impediment for such a reform. But reforms almost never emerge naturally; instead, they are the product of hard negotiation and political activism.

\footnotetext{
${ }^{98}$ Compare Justice Fields's statement in Chae Chan Ping v United States (The Chinese Exclusion Case), 130 US 581, 595-596.
} 
The possibilities of extending the demos at both the national and European levels by allowing Union citizens to vote at general elections in the member state of their residence and making long term resident third country nationals Union citizens respectively point to an alternative conception of citizenship; namely, citizenship as a network good. Existing definitions of citizenship (e.g. citizenship as status, citizenship as rights, citizenship as practice and citizenship as identity) embrace the idea that citizenship implies and flows from active connections, be they vertical, that is, between the individual and the state, or horizontal, that is, between the individual and the community (the nation) which endows him/her with identity, or both. The European Union legal order has extended the network and new connecting lines have been developed between individuals and normative orders beyond the nation-state. More importantly, individuals, in both their personal and corporate identities, can shift subject positions and activate their link with a normative system (i.e., the human rights regime or the EU) when their link with another normative system either is blocked or fails to yield a desirable outcome. Individuals are thus no longer locked within a single, unified and finite network commanding unqualified allegiance. Rather, they are members of and participants in multiple associative networks to which rights and obligations are attached. In addition, citizens are not only embedded within webs of interactions and reciprocal relations among other units, persons, and groups exhibiting mutual concern about the future of social co-operation, but their identities are also produced within such webs of social relationships.

The principle of domicile can best embody the conception of citizenship as a network good. Whereas national citizenship denotes formal membership to a nation state to which a person owes allegiance, domicile indicates the various connections and bonds of association that a person has with a political community and its legal system from which rights and obligations flow. In this respect, domicile could either reflect the special connection that one has with the country in which (s)he has his/her permanent home or the connection one has with a country by virtue of his/her birth within its jurisdiction or of his/her association with a person on whom (s)he 
is dependent. As already noted, national citizenship has traditionally disregarded or downplayed the connections that resident non-nationals may have with a juridicopolitical system, even though they are subject to its laws and as much a part of the public as birthright citizens. By putting emphasis on the national cum political nature of citizenship, it is thus ill equipped to capture the complexity of membership, which results in individuals taking on an identity within a community by virtue of the social facts of living, working and interacting there, and the endemic variegation of human interaction. Yet the latter facts can no longer be disregarded in the $21^{\text {st }}$ century. As earlier noted, a political community that is ostensibly committed to those ideals must ensure that all those consistently and permanently affected by laws and rules have a say in the political process of decision-making and are recognised as full and equal members. And although any democratic community has a legitimate interest in limiting political participation to persons who are concerned about its future and are committed to its welfare, residence, participation in the web of socio-economic interactions for an indefinite period of time and contribution, be it monetary or otherwise, are good evidence of this sort of commitment. In this respect, artificial distinctions based on the political formalities of membership which result in widespread exclusion from political participation tend to corrode the democratic credentials of political cultures.

\section{Conclusion}

The foregoing discussion has highlighted the importance of embracing a process-based and reflective orientation to the study of European Union citizenship. Instead of seeking to establish, and to defend, the primacy of a specific level of citizenship, thereby importing either consciously or unconsciously an ideological bias, it is much more fruitful to start from the assumption that European Union and national citizenships are interdependent and to examine their interaction and gradual transformation. In so doing, we do not have to deny that national attachments are 
important to people. But equally, we can no longer afford to ignore the effective transformation of migrant workers into Union citizens endowed with wide rights of equal treatment in the Member State of their residence and the growing stature of Union citizenship. Nor do we need to bracket their peculiarities, or otherwise conclude that the institutional differences of national and supranational citizenships have little importance. Rather, by resisting speculative thinking about larger issues, such as whether the new developments entail the demise of national citizenship or the transcendence of the nation state paradigm, we are in a better position to understand the evolving nature of both citizenships, to venture in uncharted territories and even to gain a glimpse of what the future might bring. For, as I argued in the preceding section, European Union citizenship has made it possible to think 'the impossible'; that is, to rethink and transform citizenship. Thinking citizenship anew, reassembling the broken parts of the triptychon 'nation, culture and belonging' on more critical terms ${ }^{99}$ and institutionalising a better citizenship model, that enhances the life chances of ordinary citizens by eliminating unnecessary forms of discrimination and the hardship they create, are thus the relevant and important issues for regional as well as statist governance.

\footnotetext{
${ }^{99}$ I borrow this from Somers, 'Rights, relationality and membership: rethinking the making and meaning of citizenship', (1994) 19(1) Law and Social Inquiry 63.
} 